MATEC Web of Conferences 38, 01008 (2016)

DOI: $10.1051 /$ matecconf/20163801008

(c) Owned by the authors, published by EDP Sciences, 2016

\title{
An Experimental Study on Axial Temperature Distribution of Combustion of Dewatered Poultry Sludge in Fluidized bed combustor
}

\author{
A. H. Abbas ${ }^{1, a}$, S. A. Sulaiman ${ }^{1}$ and M. S. Aris ${ }^{2}$ \\ ${ }^{1}$ Universiti Teknologi Petronas, Department of Mechanical Engineering, 32610 Bandar Seri Iskandar, Perak Darul Ridzuan, Malaysia \\ ${ }^{2}$ PETRONAS Research Sdn. Bhd., Bangi, Malaysia
}

\begin{abstract}
A laboratory scale bubbling fluidized bed combustor was designed and fabricated to study the combustion of dewatered poultry sludge at different operational parameters. This paper present a study on the influence of equivalent ratio, secondary to primary air ratio and the fuel feed rate on the temperature distribution along the combustor. The equivalent ratio has been changed between 0.8 to $1.4 \%$ under poultry sludge feed rate of $10 \mathrm{~kg} / \mathrm{h}$ and from 0.8 to 1 under poultry sludge feed rate of $15 \mathrm{~kg} / \mathrm{h}$. The secondary to primary air ratio was varied from 0.1 to 0.5 at $0.65 \mathrm{~m}$ injection height and 1.25 equivalent ratio. The results showed that these factors had a significant influence on the combustion characteristics of poultry sludge. The temperature distribution along the combustor was found to be strongly dependent on the fuel feed rate and the equivalent ratio and it increased when these two factors increased. However, the secondary air ratio increased the temperature in the lower region of the combustor while no significant effect was observed at the upper region of the combustor. The results suggested that the poultry sludge can be used as a fuel with high thermal combustor efficiency.
\end{abstract}

\section{Introduction}

The ongoing utilization of conventional fuels worldwide has brought to improve the study in the area of renewable energy technologies. Among the alternative energy resources available biomass is a vital alternative energy resource. Moreover, the energy generation plants using coal combustion is recognized as the most significant causes of greenhouse gas emission [1]. Replacing coal with biomass as a renewable $\mathrm{CO}_{2}$ - neutral energy source in energy conversion systems could be an option to reduce net $\mathrm{CO}_{2}$ production. Biomass is frequently accustomed to describe plant based material, but biomass can equally apply to both animal and vegetable derived material [2]. The poultry sludge is one of the waste products generated daily from the poultry-processing industry. The slaughtering of chicken and the subsequent processes in the poultry plant generate the substantial amount of wastes such as feather, bone meal, blood and offal [3]. The poultry processing waste material will go through a series of processes before the solids are dewatered and sent-off for disposal. They enter into a waste water treatment process within the processing plant and leave with a sludge like consistency known as poultry processing dewatered sludge. Globally there are various options of managing dewatered sludge, such as applied to the land to serve as a fertilizer and soil conditioner [3], [4], sea disposal and landfilling. The legal restrictions facing landfilling and agricultural reuse and also the planned ban on sea disposal [5]-[7] result in the expectation that the role of incineration and combustion would increase in long term. A combination of direct combustion and the recovery of energy as heat and electricity is now an option worth exploring. Among the technologies available for biomass combustion, fluidized bed combustion (FBC) is one of the most promising techniques due to the following advantages: high combustion efficiency, low environmental impact, flexibility in dealing with different fuels [2], compact furnace, simple design and relatively uniform temperature. Several studies have been conducted on the combustion of biomass waste materials in fluidized bed combustors in energy production. The researches mainly focused on the combustion of varies agricultural residue biomass types: rice husk [8]-[13], rice straw and wheat straw [14]-[16], palm kernel shell [17], sunflower shell [18], peanut shell [19], cotton stalk [20], and cedar pellet. The fluidized bed combustion was also used to burn woody biomass feed stocks, such as sawdust [21]-[23] and wood [15], [24]-[26]. The search of biomass combustion in fluidized bed combustor has been expanded to burn sewage sludge [25]. Co-combustion of biomass with coal has extensively studied using different biomass types, such as rice husk, woody biomass, olive residue, cotton residue, non-recyclable paper, plastic waste, municipal solid waste, and sewage sludge [27]-[40]. The results from these studies demonstrated high combustion efficiency and acceptable emissions level. However, studies on thermochemical conversion of poultry sludge is extremely scarce; while no studies have been documented on poultry sludge combustion using fluidize bed combustors. Detail investigations of the combustion characteristics of poultry sludge using FBC are necessary in order to evaluate its

\footnotetext{
${ }^{\mathrm{a}}$ Corresponding author: engabbas78@gmail.com
} 
potential as energy source. The objective of this study was to explore a new thermal disposal method and the possibility of utilizing dewatered poultry processing sludge in a direct thermo chemical energy recovery process for utilization at the waste generation site or as a potential for solid fuel. Moreover, the effects of operating parameters like equivalence ratio, secondary air ratio and the fuel feed rate on the temperature distribution of the combustion of poultry sludge were investigated using a bubbling fluidized bed combustor.

\section{Experimental}

\subsection{Apparatus}

Experiments were carried out in a laboratoryscale fluidized bed combustor to study the influence of different operating parameters on dewatered poultry sludge combustion. Figure 1 shows the pictorial view of the of the fluidized bed combustor. The cylindrical column length $150 \mathrm{~cm}$ with the bed height up to $30 \mathrm{~cm}$ and $120 \mathrm{~cm}$ freeboard and $20 \mathrm{~cm}$ internal diameter. The combustor was made of stainless steel covered internally with $5 \mathrm{~cm}$ refractory cement layer in order to maintain the temperature. The bed material is silica sand with average size of $0.8 \mathrm{~mm}$, in all experiments the same amount of sand particles were used with a bed height of approximately 10 $\mathrm{cm}$ during fluidization. The primary air enters the unit through the perforated air distributor plate which is a steel plate of $5 \mathrm{~cm}$ thickness with 640 holes of $1 \mathrm{~mm}$ diameter. Secondary air was tangentially introduced at three different heights in order to allow studding the effect of secondary air ratio and secondary air location on the combustion efficiency, temperature distribution and the emissions. The primary and secondary air flow rate was controlled and monitored using pitot tube and U-tube manometer with manometer liquid density of $784 \mathrm{~kg} / \mathrm{m} 3$ and two manual valves separately. The sludge in the feed hopper can be continuously fed to the bottom of the combustor by a screw feeder located at $30 \mathrm{~cm}$ above the air distributor plate with various feeding rates. A threephase inverter was used to adjust the fuel feed rate by changing the screw feeder motor Speed. The feeder was characterized before used by using poultry sludge to find out the characteristic curve of the motor speed and the poultry sludge flow rate. The gaseous combustion products ascending from the fluidized bed contain the entrained solid materials, such as ash, unburned carbon and sand was sent to the cyclone to separate the solid particles from the gaseous. . A diesel burner was used to heat up the sand and get proper combustion initiation of the poultry sludge. The data logger (Pico TC 08) and computer for data acquisition was used to collect the temperature distribution at six different locations above the air distributer by using type$\mathrm{K}$ thermocouples. The temperature was recorded every 5 sec.

\subsection{Operation procedures}

The start-up procedure for each combustion test consisted of a series of equipment checks. The gas analyzer and the computer were activated to monitor the exhaust gas composition and the FBC temperature. The sand was preheated using the diesel burner, when the temperature of the sand reached the ignition temperature of the poultry sludge (around $300 \mathrm{oC}$ ) the diesel burner was turned off. To run the combustion process the fuel feeder started to feed the sludge at constant feeding rate by maintaining the feeder motor at constant speed. The air blower was supplied the desired amount of air through the air distributor plate by opening the air valve to fluidize the sand and start the combustion. At that stage the poultry sludge started to combust and the temperature of the FBC is increased very fast due to energy released from the combustion process. Then the operation parameter were adjusted to fit the scheduled operation condition and the experiment was allowed to run for around 15 min to reach stable condition. The temperature distribution results and emission results were collected according to the time interval mentioned earlier. After collecting the results the fuel feeder was stopped and the blower was kept running to burn all the sludge and remaining char inside the FBC. Then the air supply was increased to carry out the ash and remaining residuals from the $\mathrm{FBC}$ bed to the cyclone.

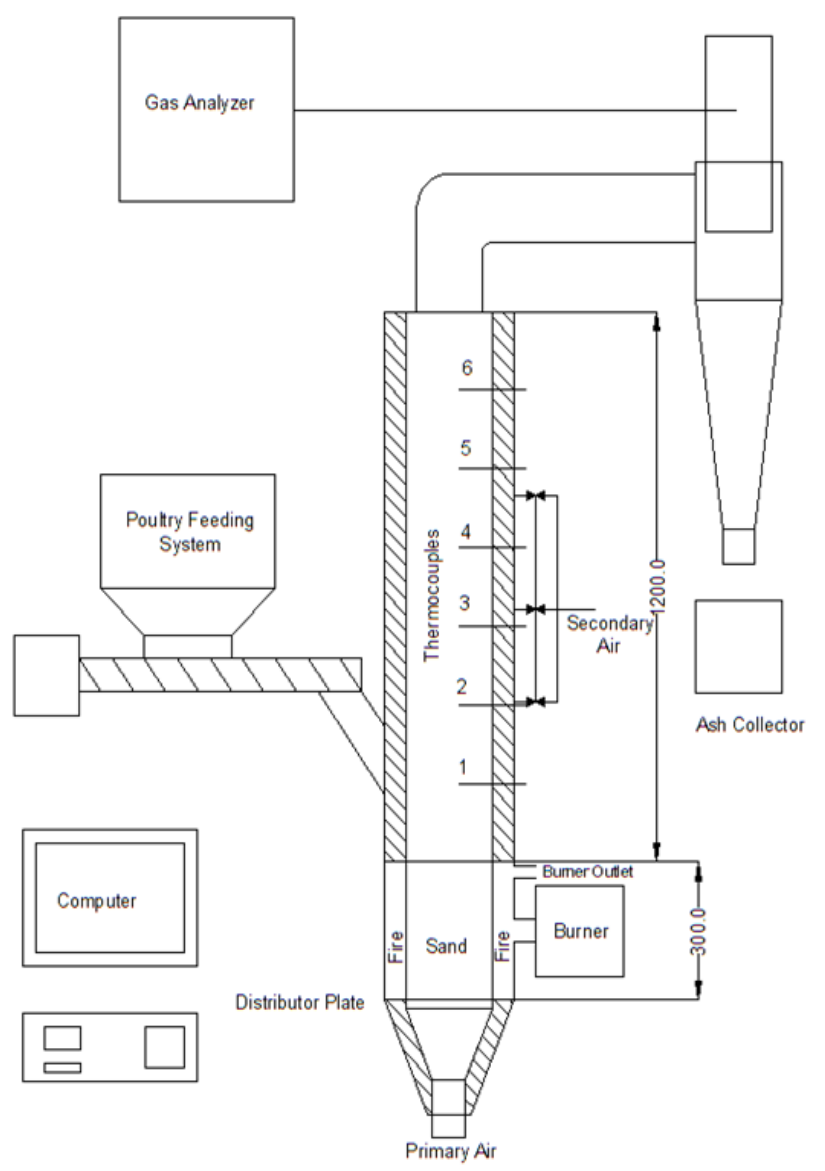

Figure 1. A schematic diagram of the FBC 


\subsection{Material}

The poultry processing sludge samples used in this study was collected from the chicken broiler factories around Malaysia that they have their own water treatment system. The respective factories are using the similar chemical coagulation and sedimentation process in their water treatment plant. This condition is good to ensure the poultry sludge is in standard condition and behavior. The samples were first dried in an oven at $105^{\circ} \mathrm{C}$ while constant checks were carried out on the sample's weight loss to record the moisture content. Experimental procedures were performed to measure the heating values and chemical compositions. The heating value procedure was carried out in accordance to ASTM D2015. The proximate analysis involved the use of a Thermogravimetric Analyzer (TGA-Perkin Elmer PYRIS1TGA) to determine moisture content (MC), volatile matter (VM), fixed carbon (FC) and ash. The ultimate analysis involved the use of a CHNS analyzer (Leco CHNS-932, VTF-900) to find the Carbon (C), Hydrogen (H), Nitrogen $(\mathrm{N})$ and Sulfur (S) content in the sample. The average values of the chemical and physical properties of the DPS samples measured is summarized in Table 1.

Table 1. Properties of DPS samples used in this study

\begin{tabular}{|c|c|}
\hline Property & Average \\
\hline Proximate analysis (wt \%) & \\
\hline Moisture content & 4 \\
\hline Volatile matter & 75 \\
\hline Fixed carbon & 13 \\
\hline Ash & 8 \\
\hline Ultimate analysis (wt \%) & 68.96 \\
\hline Carbon & 9.78 \\
\hline Hydrogen & 3.14 \\
\hline Nitrogen & 0.27 \\
\hline Sulfur & 54.8 \\
\hline Oxygen & $33.97 \pm 1.72$ \\
\hline Higher heating value $(\mathrm{MJ} / \mathrm{Kg})$ &
\end{tabular}

\section{Results and discussions}

The temperature distribution is considered one of the important parameters that can be used to study the combustion performance of the fluidized bed combustors. So the temperature distribution needs to be observed at different location along the combustor. The temperature distribution of poultry sludge combustion in fluidized bed combustor was closely monitored at different operational conditions.

Figure 2 shows the effect of the equivalent ratio (ER) on the axial temperature distribution of the combustion of poultry sludge. The poultry sludge feed rate was $10 \mathrm{~kg} / \mathrm{h}$ and no secondary air was introduced.

It can be seen that the temperature in the lower and upper region increased with the equivalent ratio but the effect was more obvious in the upper region. This observation indicates that the amount of fuel burned in the free board increased with the increase of the equivalent ratio or the amount of air because the air entrained the fuel to the upper region. The maximum and minimum temperatures in the lower region were found to be around $710^{\circ} \mathrm{C}$ and $600^{\circ} \mathrm{C}$ at equivalent ratios $1.4 \%$ and $0.6 \%$, respectively. While the maximum and minimum temperature in the upper region were $575^{\circ} \mathrm{C}$ and $260^{\circ} \mathrm{C}$ respectively at the same equivalent ratios. At equivalent ratio $1.4 \%$ the temperature difference between the lower and upper region was around $100^{\circ} \mathrm{C}$ while it was $300^{\circ} \mathrm{C}$ at $0.6 \%$ equivalent ratio. This indicates that no combustion took place in the upper region at low equivalent ratio and the combustion process was completed in the lower section.

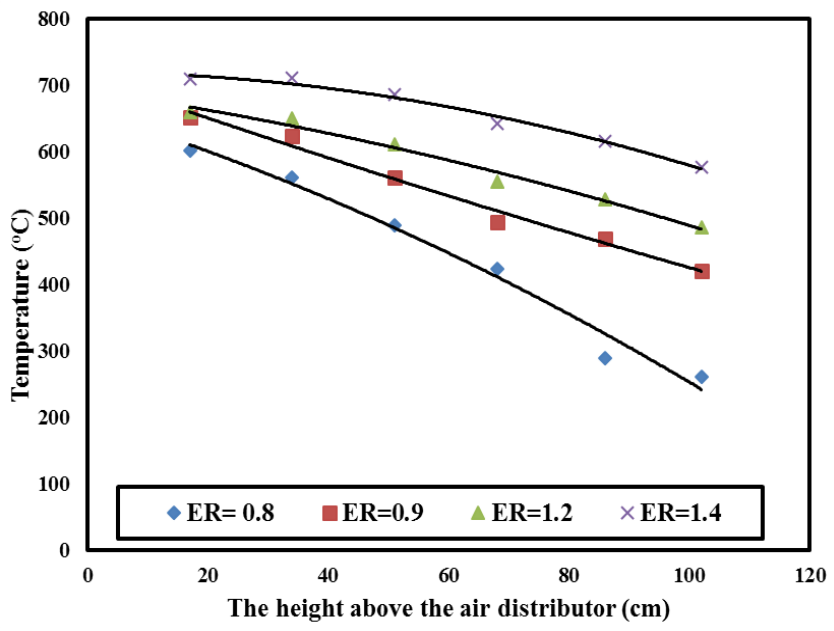

Figure 2. Temperature distribution of poul try sludge combustion at fuel rate $10 \mathrm{~kg} / \mathrm{h}$.

The effect of fuel feed rate on the axial temperature distribution of the combustion of poultry sludge in fluidized bed combustor was investigated. Figure 3 shows the effect of equivalent ratio in the case of $15 \mathrm{~kg} / \mathrm{h}$ fuel feed rate and without introducing secondary air.

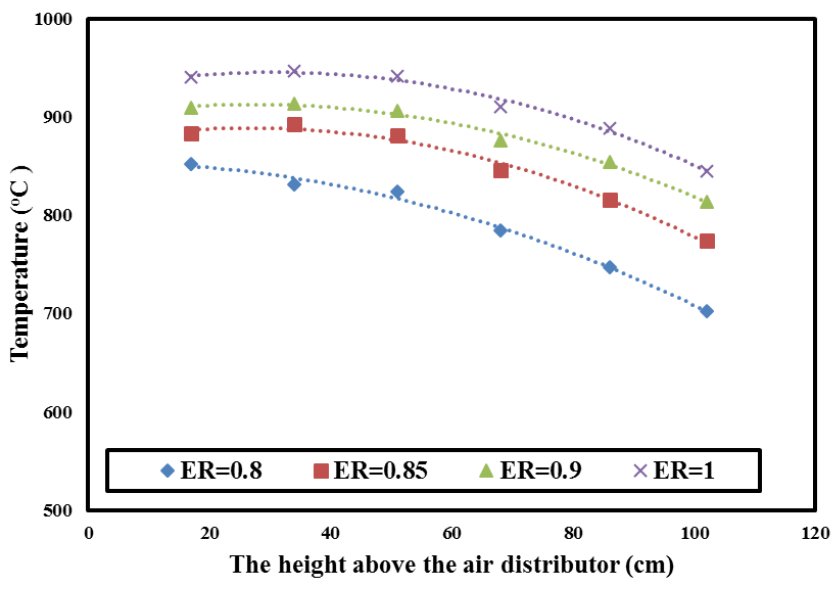

Figure 3. Temperature distribution of poultry sludge combustion at fuel rate $15 \mathrm{~kg} / \mathrm{h}$.

It can be seen that the axial temperature distribution is strongly dependent on the fuel feed rate. The temperature 
when firing $15 \mathrm{~kg} / \mathrm{h}$ was much higher than $10 \mathrm{~kg} / \mathrm{h}$ as shown in Figure 3 and Figure 4 respectively. However, in both cases the temperature in the lower and the upper region increased with the increase in the equivalent ratio. More increase in the equivalent ratio as primary air in the case firing $15 \mathrm{~kg} / \mathrm{h}$ brought unburnt fuel to the cyclone and most of the combustion process occurred in the upper part and in the cyclone as presented in Figure 4. As a result, the secondary air was introduced tangentially to increase the equivalent ratio to the required limit and at the same time kept the combustion process in the combustor zone by introducing part of the air as primary air and the rest as a secondary air.

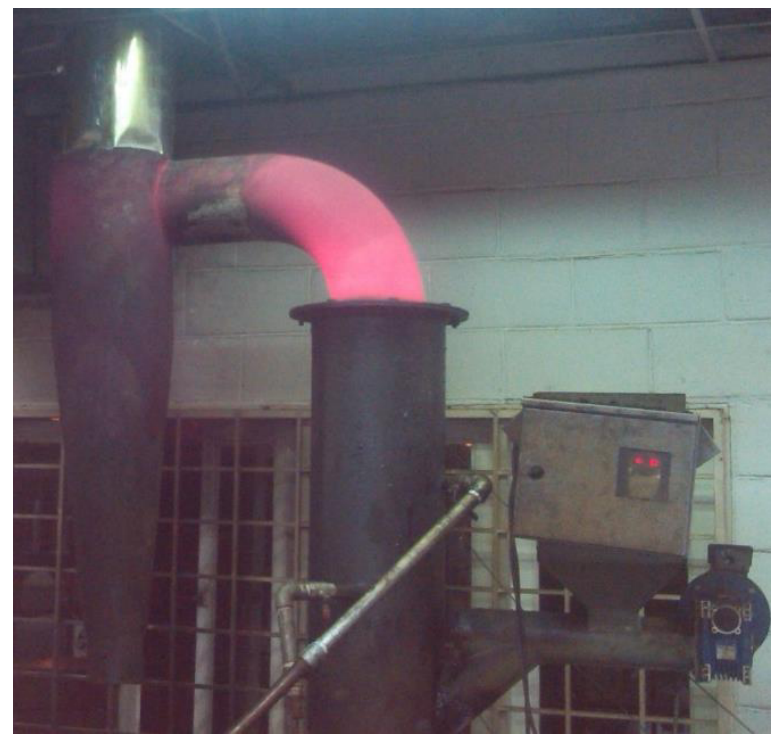

Figure 4. The effect of the combustion on the cyclone at high amount of primary air.

Figure 5 depicts the effect of secondary air ratio on the axial temperature distribution along the fluidized bed combustor in the case of $15 \mathrm{~kg} / \mathrm{h}$ fuel feed rate, 1.25 equivalent ratio and $0.65 \mathrm{~m}$ secondary air location (SAL). The results showed that the axial temperature increased with the secondary air ratio in the lower region of the combustor while no significant effect was observed at the upper region of the combustor. This finding agreed with results obtained in [8], [32]. This observation can be explained by the decrease in the convection loss and increase in the residence time. Because the increase in the secondary air was accompanied by a decrease in the primary air and therefore, increasing the bed temperature. This finding was is in agreement with the results reported in [38] who studied the co-combustion of municipal solid waste and Thai lignite in a laboratory scale bubbling fluidized bed combustor. In the secondary air injection area the temperature dropped slightly in the upper region owing the secondary air consumed energy to reach the combustion temperature and this result also supported by Madhiyanon et al. [27]. The highest temperature was observed at the fuel injection area for all ranges of secondary air ratio due to the high fuel concentration. This observation was in agreement with finding of Xie et al. [29] who studied the combustion of forest biomass waste in bubbling fluidized bed combustor. The temperature of the fluidized bed combustor was quite uniform throughout the combustor except at the fuel injection area. This was mainly due to the high volatile matter in poultry sludge and lower fixed carbon which indicates better combustion of volatile matter in the freeboard area. This uniformity indicates that the injection of secondary air improved the combustion process especially in the upper region because it was burned the volatile matters and the unburned particles.

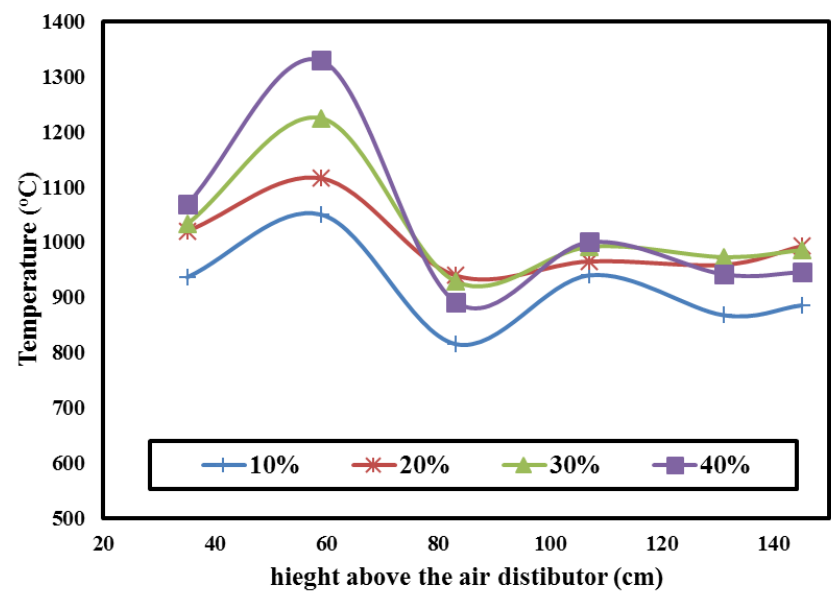

Figure 5. The axial temperature distribution at different secondary air ratio (Fuel feed rate $15 \mathrm{~kg} / \mathrm{h}, \mathrm{ER}=1.25$ and $\mathrm{SAL}=0.65 \mathrm{~m})$

\section{Conclusions}

The results from this study showed that the dewatered poultry sludge can be combusted in fluidize bed combustor without auxiliary fuel and it can be used as a fuel source for power generation. The influence of the operation parameters on the temperature distribution along the fluidized bed combustor was also investigated. When the poultry feed rate was $10 \mathrm{~kg} / \mathrm{h}$ the combustion process was completed in the lower section but the temperature was found to be relatively low. An increase in the equivalent ratio as primary air in the case firing with $15 \mathrm{~kg} / \mathrm{h}$ brought unburnt fuel to the cyclone, and most of the combustion process occurred in the upper part and in the cyclone. The secondary air was introduced tangentially to improve the combustion process and keep it within the combustion zone by introducing part of the air as primary air and the rest as a secondary air. The results also showed that the axial temperature increased with the secondary air ratio in the lower region of the combustor while no significant effect was observed at the upper region of the combustor. The temperature of the fluidized bed combustor was quite uniform throughout the combustor which indicates good combustion of the volatile matter in the free board. 


\section{References}

1. A. Sarvaramini and F. Larachi, "Integrated biomass torrefaction Chemical looping combustion as a method to recover torrefaction volatiles energy," Fuel, vol. 116, pp. 158-167, (2014).

2. A. Khan, W. De Jong, P. J. Jansens, and H. Spliethoff, "Biomass combustion in fluidized bed boilers: Potential problems and remedies," Fuel Process. Technol., vol. 90, no. 1, pp. 21-50, Jan. (2009).

3. C. Marculescu and C. Stan, "Poultry processing industry waste to energy conversion," Energy Procedia, vol. 6, pp. 550-557, (2011).

4 M. Himanen and K. Hänninen, "Bioresource Technology Composting of bio-waste, aerobic and anaerobic sludges - Effect of feedstock on the process and quality of compost," Bioresour. Technol., vol. 102, no. 3, pp. 2842-2852, (2011).

5 J. Werther and T. Ogada, "Sewage sludge combustion," Prog. Energy Combust. Sci., vol. 25, pp. 55-116, (1999).

6. S. Donatello and C. R. Cheeseman, "Recycling and recovery routes for incinerated sewage sludge ash ( ISSA ): A review," Waste Manag., vol. 33, no. 11, pp. 2328-2340, (2013).

7. M. Francisca Gómez-Rico, R. Font, A. Fullana, and I. Martín-Gullón, "Thermogravimetric study of different sewage sludges and their relationship with the nitrogen content," J. Anal. Appl. Pyrolysis, vol. 74, no. 1-2, pp. 421-428, Aug. (2005).

8. F. P. Qian, C. S. Chyang, K. S. Huang, and J. Tso, "Combustion and NO emission of high nitrogen content biomass in a pilot-scale vortexing fluidized bed combustor.," Bioresour. Technol., vol. 102, no. 2, pp. 1892-8, Jan. (2011).

9. K. Sirisomboon, V. I. Kuprianov, and P. Arromdee, "Effects of design features on combustion efficiency and emission performance of a biomass-fuelled fluidized-bed combustor," Chem. Eng. Process. Process Intensif., vol. 49, no. 3, pp. 270-277, Mar. (2010)

[10. T. Madhiyanon, a Lapirattanakun, P. Sathitruangsak, and S. Soponronnarit, "A novel cyclonic fluidizedbed combustor ( $\psi$-FBC): Combustion and thermal efficiency, temperature distributions, combustion intensity, and emission of pollutants," Combust. Flame, vol. 146, no. 1-2, pp. 232-245, Jul. (2006).

11. V. I. Kuprianov, R. Kaewklum, K. Sirisomboon, P. Arromdee, and S. Chakritthakul, "Combustion and emission characteristics of a swirling fluidized-bed combustor burning moisturized rice husk," Appl. Energy, vol. 87, no. 9, pp. 2899-2906, Sep. (2010).

12. W. Permchart and V. I. Kouprianov, "Emission performance and combustion efficiency of a conical fluidized-bed combustor firing various biomass fuels," Bioresour. Technol., vol. 92, no. 1, pp. 83-91, Mar. (2004)

13. K. Janvijitsakul and V. I. Kuprianov, "Similarity and modeling of axial $\mathrm{CO}$ and $\mathrm{NO}$ concentration profiles in a fluidized-bed combustor (co-)firing biomass fuels," Fuel, vol. 87, no. 8-9, pp. 1574-1584, Jul. (2008).
14. W. Lin, K. Dam-Johansen, and F. Frandsen, "Agglomeration in bio-fuel fired fluidized bed combustors," Chem. Eng. J., vol. 96, no. 1-3, pp. 171185, Dec. (2003).

15. P. Thy, B. M. Jenkins, R. B. Williams, C. E. Lesher, and R. R. Bakker, "Bed agglomeration in fluidized combustor fueled by wood and rice straw blends," Fuel Process. Technol., vol. 91, no. 11, pp. 1464 1485, Nov. (2010).

16. M. A. Youssef, S. S. Wahid, M. a. Mohamed, and A. a. Askalany, "Experimental study on Egyptian biomass combustion in circulating fluidized bed," Appl. Energy, vol. 86, no. 12, pp. 2644-2650, Dec. (2009).

17. P. Ninduangdee and V. I. Kuprianov, "Combustion of palm kernel shell in a fluidized bed: Optimization of biomass particle size and operating conditions," Energy Convers. Manag., vol. 85, pp. 800-808, Sep. (2014).

18. P. Arromdee and V. I. Kuprianov, "A comparative study on combustion of sunflower shells in bubbling and swirling fluidized-bed combustors with a coneshaped bed \&," Chem. Eng. Process. Process Intensif., vol. 62, pp. 26-38, (2012).

19. F. Duan, J. Zhang, C. Chyang, Y. Wang, and J. Tso, "Combustion of crushed and pelletized peanut shells in a pilot-scale fl uidized-bed combustor with fl ue gas recirculation," Fuel Process. Technol., vol. 128, pp. 28-35, (2014).

20. Z. Sun, J. Shen, B. Jin, and L. Wei, "Combustion characteristics of cotton stalk in FBC," Biomass and Bioenergy, vol. 34, no. 5, pp. 761-770, May (2010).

21. V. I. Kouprianov and W. Permchart, "Emissions from a conical FBC fired with a biomass fuel," Appl. Energy, vol. 74, no. 3-4, pp. 383-392, Mar. (2003).

22. K. V. N. S. Rao and G. V. Reddy, "Effect of secondary air injection on the combustion efficiency of sawdust in a fluidized bed combustor," Brazilian J. Chem. Eng., vol. 25, no. 01, pp. 129-141, (2008).

23. S. Zhu and S. W. Lee, "Co-combustion performance of poultry wastes and natural gas in the advanced Swirling Fluidized Bed Combustor (SFBC).," Waste Manag., vol. 25, no. 5, pp. 511-8, Jan. (2005).

24. D. R. Sudhakar, K. S. Reddy, A. K. Kolar, and B. Leckner, "Fragmentation of wood char in a laboratory scale fluidized bed combustor," Fuel Process. Technol., vol. 89, no. 11, pp. 1121-1134, Nov. (2008).

25. R. Chirone, P. Salatino, F. Scala, R. Solimene, and M. Urciuolo, "Fluidized bed combustion of pelletized biomass and waste-derived fuels," Combust. Flame, vol. 155 , no. 1-2, pp. 21-36, Oct. (2008).

26. F. Eldabbagh, a. Ramesh, J. Hawari, W. Hutny, and J. a. Kozinski, "Particle-metal interactions during combustion of pulp and paper biomass in a fluidized bed combustor," Combust. Flame, vol. 142, no. 3, pp. 249-257, Aug. (2005).

27. T. Madhiyanon, P. Sathitruangsak, and S. Soponronnarit, "Co-combustion of rice husk with coal in a cyclonic fluidized-bed combustor ( $\psi$-FBC)," Fuel, vol. 88, no. 1, pp. 132-138, Jan. (2009). 
28. T. Madhiyanon, P. Sathitruangsak, and S. Soponronnarit, "Co-firing characteristics of rice husk and coal in a cyclonic fluidized-bed combustor $(\Psi-$ FBC) under controlled bed temperatures," Fuel, vol. 90, no. 6, pp. 2103-2112, Jun. (2011).

29. L. W. Xie Jian-jun, Yang Xue-min, Zhang lie, Song Wen-li, "Emissions of SO2, NO and N20 in a circulating fluidized bed combustor during co-firing coal and biomass," J. Environ. Sci., vol. 19, pp. 109117, (2007).

30. T. Madhiyanon, P. Sathitruangsak, and S. Soponronnarit, "Influences of coal size and coalfeeding location in co-firing with rice husks on performance of a short-combustion-chamber fluidized-bed combustor (SFBC)," Fuel Process. Technol., vol. 92, no. 3, pp. 462-470, Mar. (2011).

31. P. Sathitruangsak, T. Madhiyanon, and S. oponronnarit, "Rice husk co-firing with coal in a short-combustion-chamber fluidized-bed combustor (SFBC)," Fuel, vol. 88, no. 8, pp. 1394-1402, Aug. (2009).

32. M. Varol, A. T. Atimtay, and H. Olgun, "Emission characteristics of co-combustion of a low calorie and high-sulfur-lignite coal and woodchips in a circulating fluidized bed combustor: Part 2. Effect of secondary air and its location," Fuel, vol. 130, pp. 1-9, Aug. (2014).

33. M. Varol, A. T. Atimtay, H. Olgun, and H. Atakül, "Emission characteristics of co-combustion of a low calorie and high sulfur-lignite coal and woodchips in a circulating fluidized bed combustor: Part 1. Effect of excess air ratio," Fuel, vol. 117, pp. 792-800, Jan. (2014).
34. A. T. Atimtay and H. Topal, "Co-combustion of olive cake with lignite coal in a circulating fluidized bed," Fuel, vol. 83, no. 7-8, pp. 859-867, May (2004).

35. A. T. Atimtay and M. Varol, "Investigation of cocombustion of coal and olive cake in a bubbling fluidized bed with secondary air injection," Fuel, vol. 88, no. 6, pp. 1000-1008, Jun. (2009).

36. Z. Gogebakan, Y. Gogebakan, N. Selçuk, and E. Selçuk, "Investigation of ash deposition in a pilotscale fluidized bed combustor co-firing biomass with lignite.," Bioresour. Technol., vol. 100, no. 2, pp. 1033-6, Jan. (2009).

37. D. Boavida, P. Abelha, I. Gulyurtlu, and I. Cabrita, "Co-combustion of coal and non-recyclable paper and plastic waste in a fluidised bed reactor," Fuel, vol. 82, no. 15-17, pp. 1931-1938, Oct. (2003).

38. K. Suksankraisorn, S. Patumsawad, P. Vallikul, B. Fungtammasan, and a Accary, "Co-combustion of municipal solid waste and Thai lignite in a fluidized bed," Energy Convers. Manag., vol. 45, no. 6, pp. 947-962, Apr. (2004).

39. B. Leckner, L.-E. Åmand, K. Lücke, and J. Werther, "Gaseous emissions from co-combustion of sewage sludge and coal/wood in a fluidized bed," Fuel, vol. 83, no. 4-5, pp. 477-486, Mar. (2004).

40. T. Shimizu and M. Toyono, "Emissions of NOx and $\mathrm{N} 2 \mathrm{O}$ during co-combustion of dried sewage sludge with coal in a circulating fluidized bed combustor," Fuel, vol. 86, no. 15, pp. 2308-2315, Oct. (2007). 